\title{
Anthropogenic Impacts on Fish Populations in Lake Cayo (Republic of Congo, Central Africa)
}

\author{
Armel Ibala Zamba1,2* ${ }^{1}$, Magloire Boungou33, Tenda Hélène Dembe Louvinguila1,2, \\ Victor Mamonekene1,2 (D, Ronick Kombo1, Ephraim Kamba1, Gad Boukou1, \\ Lérège Batiabo Mikembi², Freedom Honest Poaty Ngot² ${ }^{2}$ Parisse Akouango ${ }^{1}$
}

\author{
${ }^{1}$ Laboratory of Animal Productions and Biodiversity, ENSAF, Marien Ngouabi University, Brazzaville, Republic of the Congo \\ ${ }^{2}$ Laboratory of Research of Animal Biology and Ecology, IRSEN, Brazzaville, Republic of the Congo \\ ${ }^{3}$ Laboratory Animal Biology and Ecology, Joseph University KI-Zerbo, Ouagadougou, Burkina Faso \\ Email: ^ibalaszamba@yahoo.fr
}

How to cite this paper: Ibala Zamba, A., Boungou, M., Louvinguila, T.H.D., Mamonekene, V., Kombo, R., Kamba, E., Boukou, G., Mikembi, L.B., Ngot, F.H.P. and Akouango, P. (2020) Anthropogenic Impacts on Fish Populations in Lake Cayo (Republic of Congo, Central Africa). Open Journal of Ecology, 10, 757-767.

https://doi.org/10.4236/oje.2020.1012046

Received: October 25, 2020

Accepted: December 1, 2020

Published: December 4, 2020

Copyright $\odot 2020$ by author(s) and Scientific Research Publishing Inc. This work is licensed under the Creative Commons Attribution International License (CC BY 4.0).

http://creativecommons.org/licenses/by/4.0/

\begin{abstract}
Ichthyofaunal diversity and the impact of anthropogenic activities on fish population assemblages were studied in Lake Cayo, a small lake located in the coastal region of the Republic of Congo. Twelve stations were sampled twice over a two-year period. Fishing techniques following standardized methods utilizing monofilament gill nets, and nine environment variables were measured at each station. A total of 11,361 specimens comprising 30 species in 28 genera and 18 families were collected with the Cichlidae being the most diversified. Redundancy Analysis with forward selection coupled with Monte Carlo permutation tests identified depth, $\mathrm{pH}$ and substrate as accounting for $57.7 \%$ of the total variance among the nine variables sampled $(\mathrm{p}<0.05)$. The low Shannon's diversity $(1.16 \pm 0.33)$ and Equitability $(0.43 \pm 0.12)$ indices at all sites, suggest that the Lake Cayo system is in poor ecological health.
\end{abstract}

\section{Keywords}

Fish, Diversity, Ecological Health, Lake Cayo, Lower Guinea

\section{Introduction}

Continental aquatic ecosystems are particularly affected by anthropogenic activities, including habitat modification, introduction of exotic species, pollution, sedimentation, and overfishing [1] [2]. The consequences of these activities, now amplified by population growth and increasing pressure on natural resources, potentially endanger ichthyofaunal diversity and the biological integrity of aquatic ecosystems. While long spared such impacts, continent-wide African fresh- 
waters are now being increasingly impacted [2].

A small lake complex in the lower Loeme River basin includes two freshwater lakes, Cayo and Loufoualeba, both located in the coastal region of the Republic of Congo, about $30 \mathrm{~km}$ from the city of Pointe-Noire. Easily accessible via the Cabinda and Patra roads passing through extensive Eucalyptus plantations, this lacustrine complex is subject not only to intensive fishing pressure but is also located in a large on-shore oil exploitation area. Hence, establishing conservation and sustainable management measures for the fish populations in both lakes has become increasingly important. In an attempt to ameliorate these problems, since 2010 the lower Loeme lakes have been included as part of a Ramsar conservation site. However, ichthyological knowledge of coastal basins in the Republic of the Congo, including those in the Kouilou and Loeme drainages, is limited. Apart from data reported by [3] and in the recent compilation of [4] [5] on fish species richness across the lower Guinean ichthyofaunal province, no study of fish populations based on estimates of abundance or the drivers of fish community assemblages has previously been performed in the lower Loeme lake complex. Thus, the goal of the present study is to remedy this deficiency by more closely examining these neglected Ramsar ecosystems.

The present study provides the first report of the spatial distribution of fish species, the main environmental variables associated with species assemblages, and an assessment of the ecological health of the Lake Cayo ecosystem.

\section{Material and Methods}

\subsection{Study Area}

Fishes were collected in lake Cayo (Figure 1), which with an area of about 5.7 $\mathrm{km}^{2}$ is the larger of the lakes in the lower Loémé River basin.

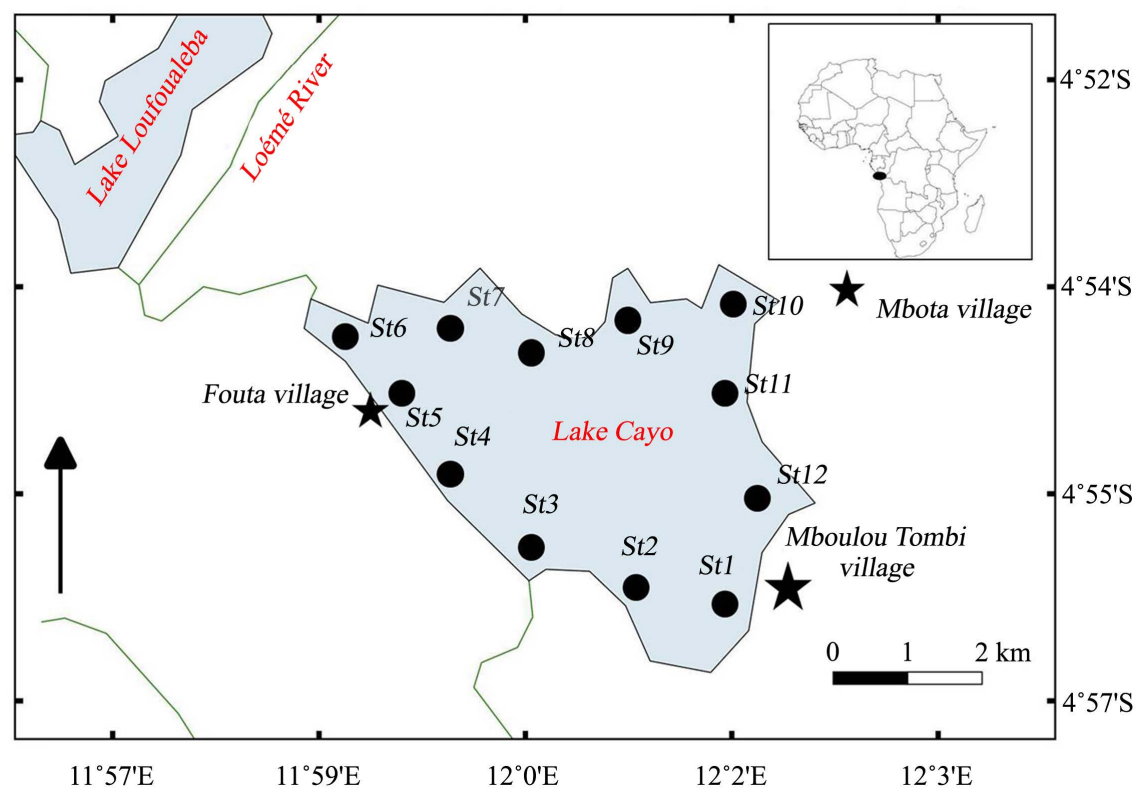

Figure 1. Lower Loémé River lake complex and sampling stations in lake Cayo. 


\subsection{Fish Sampling}

The study area comprised 12 stations throughout the lake (Figure 1). Each station was sampled twice over a two-year period from February 2018 to January 2020 , thereby including both the dry and rainy seasons. Standardized fishing techniques utilized four monofilament gill nets of $8,10,15$ and $30 \mathrm{~mm}$ mesh sizes. At each station, gill nets were set overnight from $17 \mathrm{~h}$ to $7 \mathrm{~h}$ following [6]. Fish species were identified in the field, specimens were counted by species, measured to the nearest millimeter standard length (SL), weighed (fresh total weight) to the nearest $0.01 \mathrm{~g}$, and tissue samples were taken from vouchered specimens for DNA extraction for use in subsequent studies. Samples for which field identification was uncertain were preserved in 10\% formalin for subsequent identification in the laboratory of the Ichthyology Department of the American Museum of Natural History (AMNH). The classification of the families follows [7], with genera and species in alphabetical order.

\subsection{Environmental Data}

Prior to fish sampling nine environmental parameters were measured at each station (Table 1), with a sampling protocol following [6]. Variables included are: altitude (measured in $\mathrm{m}$ with a handheld Garmin GPSmap 64st); depth (in m, measured with an echo-sounder Echotest II Plastimo); $\mathrm{pH}$, water temperature (in ${ }^{\circ} \mathrm{C}$ ), salinity (in ppm), and conductivity $(\mu \mathrm{S} / \mathrm{cm}$ ) (all measured with an Amtast multiparameter tester). The following substrate categories were identified and scored as \%: sand, mud, or plant debris. Data for all nine parameters were collected at the beginning, middle, and end of each station, and all sampled stations were georeferenced using a GPSmap 64st. For each station, values given are mean values for 4 gill-nets, 2 seasons and 2 years (total $N=16$ ).

Table 1. Physico-chemical characteristics measured. ${ }^{*}=$ Mean values for 4 gill-nets, 2 seasons and 2 years (total $N=16$ ).

\begin{tabular}{|c|c|c|c|c|c|c|c|c|c|c|c|c|c|}
\hline \multirow{2}{*}{ Variables } & \multirow{2}{*}{ Code } & \multicolumn{12}{|c|}{ Stations } \\
\hline & & St1 & St2 & St3 & St4 & St5 & St6 & St7 & St8 & St9 & St10 & St11 & St12 \\
\hline Altitude & Alt & 3 & 3 & 4 & 4 & 5 & 4 & 4 & 5 & 3 & 4 & 4 & 3 \\
\hline Depth $(\mathrm{m})^{*}$ & Dep & 1.08 & 1.00 & 1.10 & 0.99 & 1.05 & 1.51 & 1.43 & 1.23 & 1.71 & 0.73 & 1.10 & 0.76 \\
\hline $\mathrm{pH}^{*}$ & $\mathrm{pH}$ & 8.29 & 10.38 & 10.35 & 9.82 & 10.31 & 10.39 & 10.37 & 9.94 & 10.41 & 10.26 & 10.00 & 10.54 \\
\hline $\begin{array}{l}\text { Conductivity } \\
(\mu \mathrm{S} / \mathrm{cm})^{*}\end{array}$ & Cond & 21.00 & 39.63 & 38.50 & 35.13 & 35.13 & 35.75 & 36.00 & 35.88 & 38.25 & 39.75 & 35.38 & 35.38 \\
\hline $\begin{array}{l}\text { Salinity } \\
(\mathrm{ppm})^{*}\end{array}$ & Sal & 36.75 & 39.63 & 35.63 & 37.75 & 36.75 & 39.00 & 39.13 & 39.50 & 41.63 & 43.38 & 38.75 & 39.13 \\
\hline \multicolumn{14}{|c|}{ Substratum type (in \%) } \\
\hline Sand & Sand & 45 & 45 & 5 & 45 & 5 & 5 & 5 & 5 & 5 & 5 & 10 & 10 \\
\hline Plan debris & Pld & 30 & 30 & 60 & 30 & 60 & 60 & 60 & 60 & 60 & 60 & 30 & 30 \\
\hline Mud & Mud & 25 & 25 & 35 & 25 & 35 & 35 & 35 & 35 & 35 & 35 & 60 & 60 \\
\hline
\end{tabular}




\subsection{Statistical Analyses}

Redundancy Analysis [8] was used to investigate possible correlations between environmental variables and fish community assemblages. Therefore, two matrices covering the 12 sampled stations were constructed, one containing numerical abundance of all species collected and another of the environmental variables. Monte Carlo tests (199 permutations, $\mathrm{p}<0.05$ ) were used to select environmental variables explaining variation in fish species data. Prior to ordination, fish abundance and environmental data were transformed to better meet the assumptions of normality [9] using respectively $\log _{10}(x+1)$ and $\ln (x+1)$ or $\arcsin \sqrt{x}$ for percentages. In addition, the ecological health of the lake was evaluated, calculating three ecological diversity indices [10] [11]: Species richness $S$; Shannon index $H^{\prime}$ with its Shannon maximum index $H_{\max }^{\prime}$ [12]; and Equitability $R$ [13].

Species richness $(S)$ is the number of species represented in the catches. Shannon diversity index $(H)$ were calculated according the formula:

$$
H^{\prime}=\sum_{i=1}^{S} P_{i} \ln P_{i}
$$

With $P_{i}=n_{i} / N ; N$ being the total number of individuals obtained for all species, $n_{i}$ is the number of individuals of species $i$ and $P_{i}$ the relative abundance of species $i$ in the sample. Shannon index varies between 0 and $H^{\prime}$ maximum, calculated according to the formula:

$$
H_{\text {max }}^{\prime}=\ln S
$$

The Equitability $(R)$ indicates whether individuals are equally distributed among the species of the target area, and varies between 0 and 1 . It tends towards 0 when the totality of catches is almost entirely of one species, and towards 1 when all species have the same abundance within given sample. It is calculated using the formula:

$$
R=\frac{H^{\prime}}{H_{\max }^{\prime}}
$$

The analysis was performed using CANOCO (Canonical Community Ordination, version 4.5) [8], for multivariate analysis (RDA); PRIMER version 5 [14] for univariate analysis $\left(S, H^{\prime}\right.$ and $\left.R\right)$.

\section{Results}

\subsection{Species Composition}

Fish composition is provided in Table 2. A total of 11,361 specimens comprising 30 species belonging to 28 genera and 18 families were collected. Among families represented Cichlidae is the most species rich (5 species), with the remaining families represented by only 1 to 3 species. Among these is a putatively undescribed species of Enteromius, and a single introduced species (Heterotis niloticus). 
Table 2. List of species collected, their code and relative abundance.

\begin{tabular}{|c|c|c|c|c|c|c|c|c|c|c|c|c|c|}
\hline Families and species & Code & St1 & St2 & St3 & St4 & St5 & St6 & St7 & St8 & St9 & St10 & St11 & St12 \\
\hline \multicolumn{14}{|l|}{ Arapaimidae } \\
\hline Heterotis niloticus (Cuvier, 1829) & Hen & 0.00 & 0.10 & 0.00 & 0.00 & 0.00 & 0.63 & 0.00 & 0.36 & 0.00 & 0.08 & 0.00 & 0.12 \\
\hline \multicolumn{14}{|l|}{ Mormyridae } \\
\hline Brienomyrus brachyistius (Gill, 1862) & $B r b$ & 0.45 & 0.70 & 1.23 & 0.98 & 1.21 & 11.95 & 5.81 & 1.07 & 0.35 & 0.08 & 0.24 & 0.12 \\
\hline Marcusenius moorii (Günther, 1867) & Mam & 0.45 & 0.90 & 1.09 & 0.28 & 1.69 & 1.89 & 0.81 & 2.25 & 1.24 & 0.08 & 0.12 & 0.23 \\
\hline Pollimyrus pedunculatus (David \& Poll, 1937) & Pop & 0.00 & 0.10 & 0.14 & 0.00 & 0.12 & 1.26 & 0.00 & 0.00 & 0.05 & 0.00 & 0.00 & 0.00 \\
\hline \multicolumn{14}{|l|}{ Clupeidae } \\
\hline Ethmalosa fimbriata (Bowdich, 1825) & $T t f$ & 0.00 & 0.00 & 0.00 & 0.00 & 0.00 & 0.00 & 2.70 & 0.00 & 0.00 & 0.00 & 0.00 & 0.12 \\
\hline \multicolumn{14}{|l|}{ Cyprinidae } \\
\hline Enteromius sp & Esp & 0.27 & 0.00 & 0.00 & 0.00 & 0.00 & 0.00 & 0.00 & 0.12 & 0.40 & 0.75 & 0.00 & 0.00 \\
\hline \multicolumn{14}{|l|}{ Distichodontidae } \\
\hline Neolebias spilotaenia Boulenger, 1912 & Nes & 0.00 & 0.00 & 0.14 & 0.00 & 0.00 & 0.00 & 1.35 & 0.00 & 0.00 & 0.00 & 0.00 & 0.00 \\
\hline \multicolumn{14}{|l|}{ Alestidae } \\
\hline Brycinus kingsleyae (Günther, 1896) & Brk & 2.71 & 0.00 & 1.77 & 9.55 & 0.60 & 19.81 & 17.97 & 3.20 & 8.21 & 4.22 & 0.00 & 14.99 \\
\hline Nannopetersius ansorgii (Boulenger, 1910) & Naa & 78.72 & 63.20 & 76.29 & 66.71 & 78.96 & 41.82 & 57.84 & 83.91 & 86.65 & 74.92 & 63.90 & 51.79 \\
\hline Nannopetersius lamberti Poll, 1967 & $\mathrm{Nal}$ & 0.00 & 0.00 & 0.00 & 0.00 & 0.00 & 0.00 & 0.00 & 0.00 & 0.00 & 0.15 & 3.73 & 0.00 \\
\hline \multicolumn{14}{|l|}{ Clariidae } \\
\hline Clarias jaensis Boulenger, 1909 & Clj & 0.09 & 0.00 & 0.00 & 0.00 & 0.00 & 0.00 & 0.00 & 0.00 & 0.00 & 0.00 & 0.00 & 0.00 \\
\hline \multicolumn{14}{|l|}{ Claroteidae } \\
\hline Chrysichthys dageti Risch, 1992 & Chd & 8.66 & 18.70 & 3.95 & 2.53 & 3.75 & 7.23 & 0.81 & 3.08 & 0.25 & 4.59 & 7.70 & 7.73 \\
\hline Schilbeidae & & 0.00 & 0.00 & 0.00 & 0.00 & 0.00 & 0.00 & 0.00 & 0.00 & 0.00 & 0.00 & 0.00 & 0.00 \\
\hline Parailia occidentalis (Pellegrin, 1901) & Pao & 0.45 & 1.00 & 2.32 & 0.70 & 3.75 & 1.26 & 0.95 & 2.13 & 0.84 & 0.83 & 3.01 & 0.12 \\
\hline \multicolumn{14}{|l|}{ Eleotridae } \\
\hline Dormitator lebretonis (Steindachner, 1870) & Dol & 0.72 & 0.00 & 0.54 & 0.00 & 0.00 & 1.26 & 0.54 & 1.07 & 0.15 & 0.00 & 1.08 & 0.00 \\
\hline Eleotris vittata Duméril, 1861 & $E l_{V}$ & 0.54 & 0.00 & 0.41 & 0.00 & 0.00 & 4.09 & 0.68 & 0.00 & 0.35 & 0.00 & 0.84 & 0.81 \\
\hline \multicolumn{14}{|l|}{ Gobiidae } \\
\hline Ctenogobius lepturus (Pfaff, 1933) & $C t l$ & 0.36 & 1.30 & 2.59 & 1.97 & 0.00 & 1.26 & 6.35 & 0.36 & 0.45 & 0.75 & 1.93 & 5.77 \\
\hline Gobionellus occidentalis (Boulenger, 1909) & Goo & 0.00 & 0.00 & 0.00 & 7.87 & 0.00 & 0.00 & 0.00 & 0.00 & 0.00 & 0.08 & 0.00 & 2.88 \\
\hline Sicydium crenilabrum Harrison, 1993 & Sic & 0.09 & 0.40 & 0.27 & 0.28 & 0.12 & 0.31 & 0.14 & 0.00 & 0.05 & 0.00 & 0.24 & 0.12 \\
\hline \multicolumn{14}{|l|}{ Anabantidae } \\
\hline Microctenopoma congicum (Boulenger, 1887) & Mic & 0.00 & 0.00 & 0.00 & 0.00 & 0.00 & 0.31 & 0.00 & 0.00 & 0.00 & 0.00 & 0.00 & 0.00 \\
\hline \multicolumn{14}{|l|}{ Channidae } \\
\hline Parachanna insignis (Sauvage, 1884) & Pob & 0.00 & 0.00 & 0.00 & 0.00 & 0.12 & 0.00 & 0.00 & 0.00 & 0.00 & 0.00 & 0.00 & 0.00 \\
\hline \multicolumn{14}{|l|}{ Cichlidae } \\
\hline Chilochromis duponti Boulenger, 1902 & $C d u$ & 0.00 & 0.00 & 0.00 & 0.00 & 0.48 & 0.31 & 0.00 & 0.00 & 0.00 & 0.00 & 0.00 & 0.00 \\
\hline
\end{tabular}




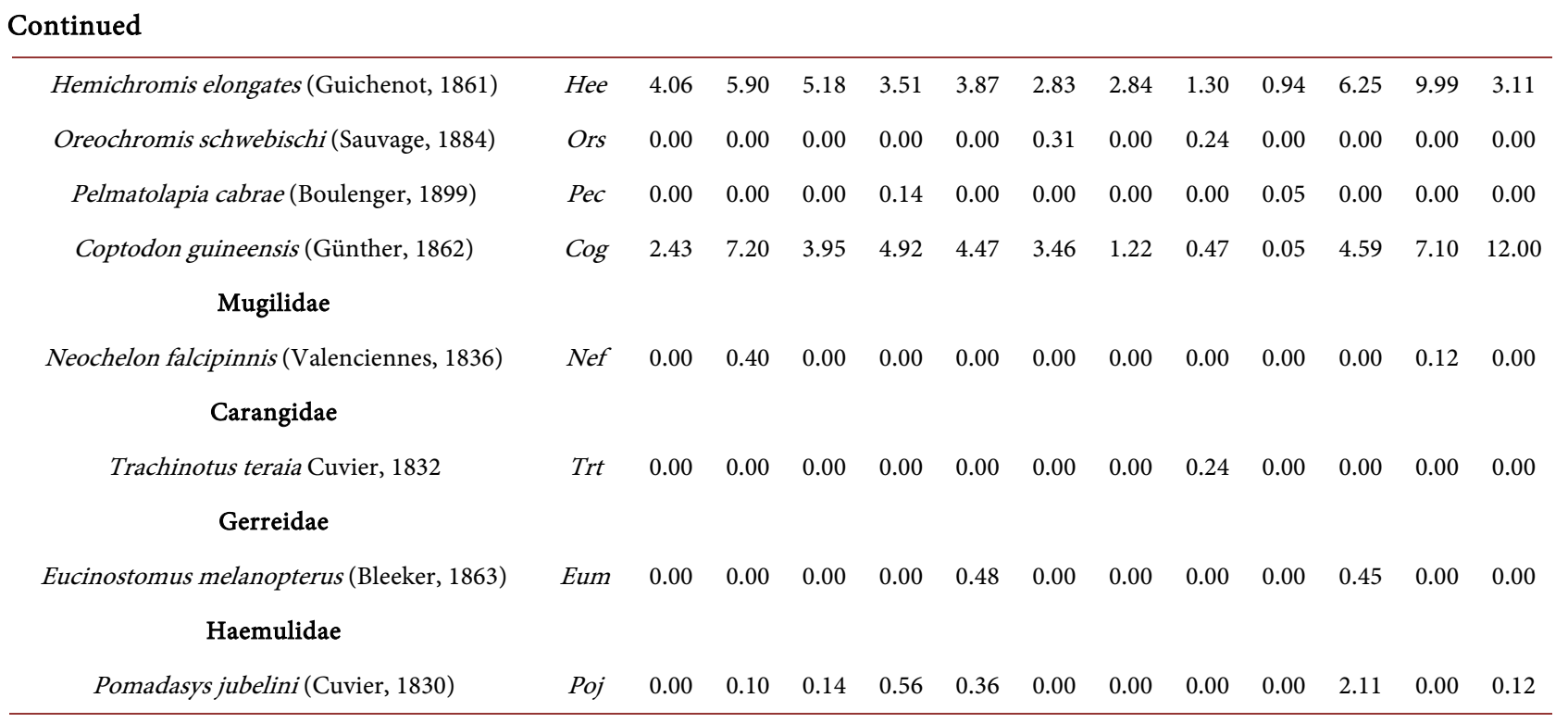

\subsection{Fish Communities, Stations, and Environmental Variables}

Results of the Redundancy Analysis (Figure 2(a) and Figure 2(b)) indicate that the first two axes $(22.3 \%$ and $13.1 \%$ respectively) express $35.4 \%$ of the cumulative variance in the fish data. Species and environmental variable correlations for both axes are high, respectively 0.95 and 0.82 . Monte Carlo permutation tests (999 iterations) also indicate that the contributions of the two first axes are significant $(\mathrm{F}=1.79 ; \mathrm{p}=0.009)$. Consequently, only these two axes were considered for data analysis. Redundancy Analysis with forward selection identified three environmental variables as accounting for $57.7 \%$ of the total variance among nine variables $(\mathrm{p}<0.05)$ : Depth, $\mathrm{pH}$ and substrate (mud). Based on these results, it appears that the three selected environmental variables have a significant $(\mathrm{p}<$ 0.05) influence on fish community assemblages in Lake Cayo.

Three groups of sampling sites are distinguished in relation to both RDA Axes 1 and 2 (Figure 2(a)): Group 1, represented by stations (St 1, 10, 11 and 12) described as across the lake from the affluent inlet of the Loeme; Group 2, composed of stations (St 6, 7, 8 and 9) described as adjacent to the affluent inlet of the Loeme; and Group 3, composed of stations (St 2, 3, 4 and 5) described as adjacent to the effluent outlet into the Loeme.

The eleven fish species found at Group 1 sites, negatively correlated with Axis 1 and positively with Axis 2, include Chrysichthys dageti, Clarias buthupogon, C. jaensis, Enteromius sp, Eucinostomus melanopterus, Hemichromis elongatus, Pomadasys jubelini, Gobionellus occidentalis, Nannopetersius ansorgii and $N$. lamberti. Those at Group 2 sites, positively correlated with Axis 1, are distinguished by an assemblage including 12 species (Brienomyrus brachyistius, Dormitator lebretonis, Eleotris vittata, Ethmalosa fimbriata, Marcusenius moorii, Microctenopoma congicum, Neolebias spilotaenia, Parailia occidentalis, Pelmatolapia cabrae, Pollimyrus pedunculatus, Oreochromis schwebischi and Trachinotus teraia). And those at Group 3 sites, negatively correlated with Axis 1 and 


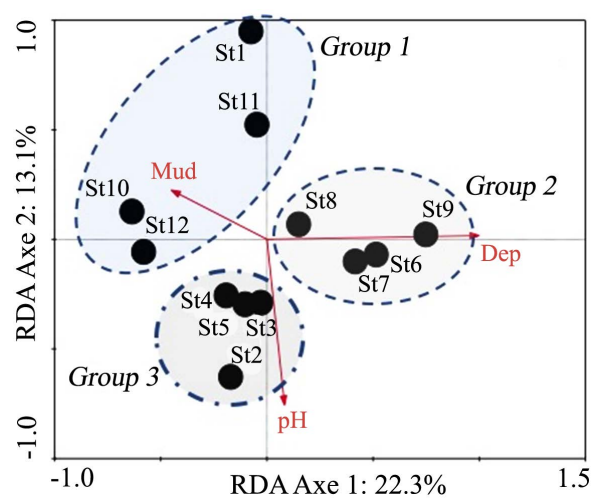

(a)

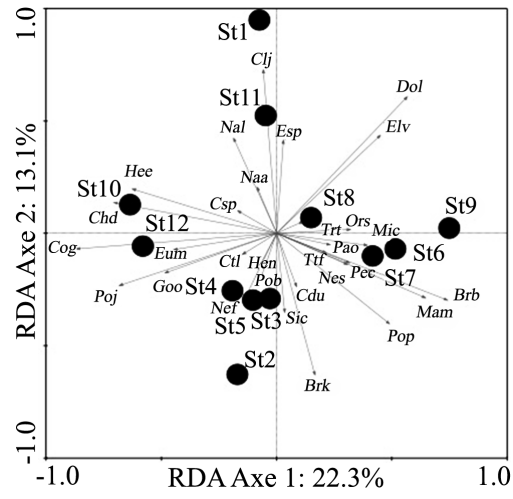

(b)

Figure 2. RDA ordination of species, stations and the two forward selected environmental variables. (a): biplot of stations and environmental variables; (b): biplot of stations and species.

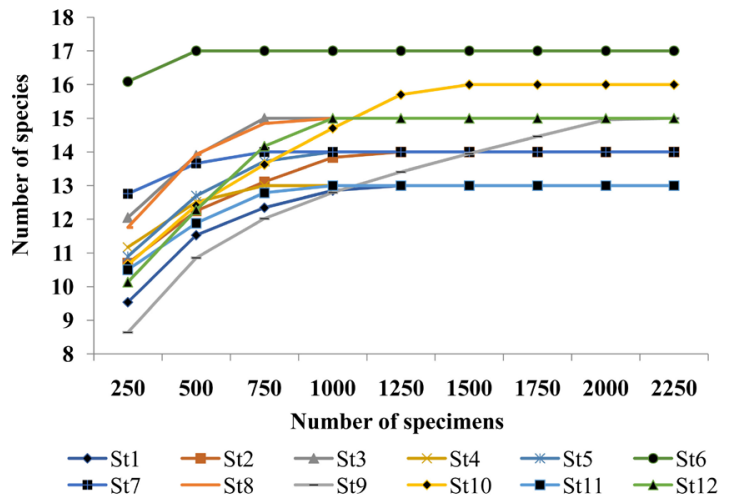

Figure 3. Rarefaction of the specific richness in each station studied (12) according to the number of specimens.

2, are composed of 7 species (Brycinus kingsleyae, Chilochromis duponti, Ctenogobius lepturus, Heterotis niloticus, Neochelon falcipinnis, Parachanna insignis, and Sicydium crenilabrum).

\subsection{Rarefaction of Species Richness}

Rarefaction curves of the species richness at each station (Figure 3) indicate that an increase in the number of specimens collected does not necessarily lead to an increase in the species richness. Thus, a sample of 318 specimens was needed to reach the maximum number of 17 species in the most diversified station (St2). While in the least diversified stations (St1, St 4 and St11, with 13 species each), respectively 712, 1079 and 831 specimens were reported.

\subsection{Ecological Diversity Indices}

Ecological diversity indices, including species richness $(S)$, Shannon index $(H)$, Shannon maximum index $\left(H_{\max }^{\prime}\right)$ and Equitability $(R)$ were calculated for each of the 12 stations (Table 3). Values of Equitability were highest 0.59 in station 6 and lowest 0.21 in station 9 . 
Table 3. Ecological diversity indices. $N$ : number of specimens; $S$ : Species richness; $H$ : Shannon index; $H_{\max }^{\prime}$ : Shannon maximum index; $R$ : Equitability.

\begin{tabular}{cccccc}
\hline Stations & $S$ & $N$ & $H^{\prime}$ & $\boldsymbol{H}_{\max }^{\prime}$ & $R$ \\
\hline St1 & 13 & 1079 & 0.80 & 2.56 & 0.31 \\
St2 & 14 & 1058 & 1.35 & 2.63 & 0.51 \\
St3 & 15 & 734 & 1.07 & 2.70 & 0.39 \\
St4 & 13 & 712 & 1.28 & 2.56 & 0.49 \\
St5 & 14 & 827 & 0.95 & 2.64 & 0.35 \\
St6 & 17 & 318 & 1.66 & 2.83 & 0.59 \\
St7 & 14 & 740 & 1.47 & 2.64 & 0.55 \\
St8 & 15 & 845 & 0.80 & 2,71 & 0.29 \\
St9 & 15 & 2022 & 0.59 & 2.71 & 0.21 \\
St10 & 16 & 1328 & 1.06 & 2.77 & 0.38 \\
St11 & 13 & 831 & 1.34 & 2.57 & 0.52 \\
St12 & 15 & 867 & 1.55 & 2.71 & 0.57 \\
\hline
\end{tabular}

\section{Discussion}

\subsection{Fish Diversity and Distribution}

In their study of fishes caught in brackish or freshwater biotopes from coastal regions of the Republic of Congo, [3] reported only six species (Eleotris vittata, Ethmalosa fimbria, Eucinostomus melanopterus, Neochelon falcipinnis, Pelmatolapia cabrae and Pomadasys jubelini) present in Lake Cayo. However, in the present study a total of 30 species is reported for the lake and this ichthyofauna is dominated by Cichlidae, despite only a single species, Pelmatolapia cabrae, being reported by [3]. All species recorded from Lake Cayo are typical of the lower Guinean ichthyofaunal province, with the exception of Heterotis niloticus, which has been widely introduced within the area for aquaculture purposes [15].

The present study represents the first ecological investigation of fishes performed in a coastal basin of the Republic of Congo, and compliments a short list of the similar studies recently undertaken in the lower Guinean ichthyofaunal province [16] [17]. Given the small size and seeming homogeneity of habitat space within Lake Cayo, a total of 30 species unevenly distributed across sites within the lake is unexpected. Yet, according to the RDA (Figure 2(b)), water depth $(22.3 \%)$ is the most important variable for fish distribution in the system, followed by $\mathrm{pH}(20.1 \%)$ and a mud substrate (15.3\%). Several authors have already shown the importance of these environmental variables in structuring fish populations in both riverine and lacustrine ecosystems in Africa [6] [16] [17] [18] [19] [20].

\subsection{Ecological Health of the Lake Cayo}

The Southwestern Coastal Equatorial ecoregion, in which Lake Cayo is located, 
has been identified as being highly vulnerable to human impacts [21]. Among these oil exploitation and logging are the main activities identified as polluting aquatic systems in the ecoregion. To these must be added increasing over exploitation of fish stocks (pers. obs.).

The three ecological diversity indices $\left(S, H^{\prime}\right.$ and $R$ ), calculated based on species abundance, revealed that in all habitat groups in the Cayo (see Figure 2(a)), the $H^{\prime}$ (Group 1: mean = 1.19; Group 2: mean $=1.13$; Group 3: mean $=1.16$ ) and $R($ Group 1: mean $=0.45$; Group 2: mean $=0.41$; Group 3: mean $=0.43)$ indices are far from approaching their maximum values, respectively $H^{\prime}$ maximum $(2.65 ; 2.72 ; 2.63)$ for $H^{\prime}$ and 1 for $R$. Even if analysis of fish communities using diversity indices does not reflect the complete organizational modalities of populations within a system, it is however known that these indices are of utility in the diagnosis of aquatic ecosystem health [22] [23]. In addition, it is well known that when all species of a community are in abundance and the environment in good ecological health, $H^{\prime}$ and $R$ indices approach their maximum values [23] [10]. This situation is not the case in the lake Cayo where Nannopetersius ansorgii dominates significantly (72.1\%) in all the stations sampled. Based on these results, it is now clear that the Lake Cayo is not in good ecological health, and as discussed below this probably reflects increasing anthropogenic activities around the lake.

\section{Conclusion}

The present study provides data on fish diversity and imbalance in terms of abundance on fish species in the lake Cayo, one of the lakes of the Lower Loeme lake complex. An imbalance which could be explained by the species Nannopetersius ansorgii, well adapted to this environment. With 30, a total of fish species reported, including a putatively undescribed species of Enteromius and a single introduced species (Heterotis niloticus), this database contributes to a better understanding of fish communities in the lower Guinean ichthyofaunal province. Water depth, $\mathrm{pH}$ and Mud are shown to have a significant influence on fish assemblages. The low values of the Shannon and Equitability indices in all the habitats sampled could indicate the negative impacts mainly from overfishing and oil pollution on the ecological health of Lake Cayo.

\section{Acknowledgements}

We would like to thank Melanie Stiassny for insightful comments on an earlier version of the manuscript. The fieldwork of AIZ (2018-2020) was provided by IRSEN institution (Republic of the Congo) and a study visit of AIZ to AMNH in 2019 was provided by the Axelrod Research Curatorship (MLJS).

\section{Conflicts of Interest}

The authors declare no conflicts of interest regarding the publication of this paper. 


\section{References}

[1] Kamdem Toham, A. and Teugels, G.G. (1999) First Data on an Index of Biotic Integrity (IBI) Based on First Assemblages for the Assessment of the Impact of the Deforestation in a Tropical West African River System. Hydrobiologia, 397, 29-38. https://doi.org/10.1023/A:1003605801875

[2] Paugy, D. and Lévêque C. (2017) Impacts of Human Activities. In: Paugy, D., Leveque, C. and Otero, O., Eds., The Inland Water Fishes of Africa: Diversity, Ecology and Human Use, Institut De Recherche Pour Le Développement, Musée Royal de l'Afrique Central, Paris, Tervuren, 459-478.

https://doi.org/10.4000/books.irdeditions.25262

[3] Daget, J. and Stauch, A. (1963) Poissons de la Rive Droite du Moyen Congo. Mission A. Stauch (Février-Avril 1961). Bulletin de P Institut de Recherche Scientifique du Congo, 2, 41-48.

[4] Stiassny, M.L.J., Teugels, G.G. and Hopkins, C.D. (2007) Poissonsd'eauxdouces et saumâtres de basse Guinée, ouest de l'Afriquecentrale. Vol. 1, IRD (Paris), MNHN (Paris), MRAC (Tervuren), collection faune et florestropicales, 42, $800 \mathrm{p}$.

[5] Stiassny, M.L.J., Teugels, G.G. and Hopkins, C.D. (2007) Poissons d'eaux douces et Saumâtres de basse Guinée, Ouest de l'Afrique Centrale. Vol. 2, Institut De Recherche Pour Le Développement, Muséum National d'Histoire Naturelle, Musée Royal de l'Afrique Central, Paris, Tervuren, 42, 603 p.

[6] Ibala Zamba, A., Mamonekene, V., Vreven, E. and Snoeks, J. (2019) Fish Community Assemblages in Relation to Environmental Variables in the Lefini River, Middle Congo River Basin (Republic of Congo). Cybium, 43, 83-95.

[7] Fricke, R., Eschmer, W.N. and Fong, J.D. (2020) Eschmeyer's Catalog of Fishes. http://researcharchive.calacademy.org/research/ichthyology/catalog/SpeciesByFamil y.asp

[8] Ter Braak, C.J.F. and Šmilauer, P. (2003) Canoco 4. Cambridge University Press, USA, $242 \mathrm{p}$.

[9] Fischer, J.R. and Paukert, C.P. (2008) Habitat Relationships with Assemblages in Minimally Disturbed Great Plains Regions. Ecology of Freshwater Fish, 17, 597-609. https://doi.org/10.1111/j.1600-0633.2008.00311.x

[10] Lobry, J., Gascuel, D. and Domain, F. (2003) La Biodiversité Spécifique des Ressources Démersales du Plateau Continental Guinéen: Utilisation d'Indice Classique Pour un Diagnostic sur l'Évolution des Écosystèmes. Aquatic Living Resources, 16, 59-68. https://doi.org/10.1016/S0990-7440(03)00010-X

[11] Lande, R (1996) Statistcs and Partitioning of Species Diversity, and Similarity among Multiple Communities. Oikos, 76, 5-13. https://doi.org/10.2307/3545743

[12] Shannon, C.E. (1948) A Mathematical Theory for Communication. Bell System Technical Journal, 27, 623-656. https://doi.org/10.1002/j.1538-7305.1948.tb00917.x

[13] Pielou, E.C. (1966) The Measurement of Diversity in Different Types of Biological Collections. Journal of Theoretical Biology, 13, 131-144. https://doi.org/10.1016/0022-5193(66)90013-0

[14] Clarke, K.R. and Gorley, R.N. (2001) Primer V5: User Manual/Tutorial. Primer-E Ltd., Plymouth, 91 p.

[15] Paugy, D. and Lévêque C. (2007) Introduced or Alien Species of Lower Guinea. In: Stiassny, M.L.J., Teugels, G.G. and Hopkins, C.D., Eds, Poissons d eaux Douces et Saumâtres de Basse Guinée, ouest de PAfrique Central, Vol. 1, Institut De Re- 
cherche Pour Le Développement, Muséum National d'Histoire Naturelle, Musée Royal de l'Afrique Central, Paris, Tervuren, 57-101.

[16] Kamdem Toham, A. and Teugels, G.G. (1997) Patterns of Microhabitat Use among Fourteen Abundant Fishes of the Lower Ntem River Basin (Cameroon). Aquatic Living Resources, 10, 289-298. https://doi.org/10.1051/alr:1997032

[17] Kamdem Toham, A. and Teugels, G.G. (1998) Diversity Patterns of Fish Assemblages in the Lower Ntem River Basin (Cameroon), with Notes on Potential Effects of Deforestation. Archiv für Hydrobiologie, 141, 421-446. https://doi.org/10.1127/archiv-hydrobiol/141/1998/421

[18] Mbega, J.D. (2004) Biodiversité des Poisons du Basin Inférieur de l'Ogooué (Gabon). Presses Universitaires de Namur, Namur, 614 p.

[19] Ibaňez, C., Oberdorff, T., Teugels, G., Mamononekene, V., Lavoué, S. Fermon, Y., Paugy, D. and Kamdem Toham, A. (2007) Fish Assemblages Structure and Function along Environmental Gradients in Rivers of Gabon (Africa). Ecology of Freshwater Fish, 16, 315-334. https://doi.org/10.1111/j.1600-0633.2006.00222.x

[20] Liyandja, T.L.D., Ibala Zamba, A., Sefu, C.A., Dianzuangani, D.L., Konda, R.K., Monsembula Iyaba, R.J.C. and Mbimbi, J.J.M.N. (2019) Environmental Influences on Fish Species Distribution in the Musolo River System, Congo River Basin (Democratic Republic of the Congo, Central Africa). European Scientific Journal, 15, 192-209. https://doi.org/10.19044/esj.2019.v15n33p192

[21] Thieme, M.L., Abell, R., Stiassny, M.L.J. and Skelton, P. (2005) Freshwater Ecoregions of Africa and Madagascar. A Conservation Assessment. Wold Wildlife Fund, Gland, $431 \mathrm{p}$.

[22] Barbault, R. (1992) Ecologie des Peuplements, Structure, Dynamique et Évolution. Masson, Paris, 273 p.

[23] Ludwig, J.A. and Renolds, J.F. (1988) Statistical Ecology: A Primer on Methods and Computing. John Wiley \& Sons, New York, 44 p. 